\title{
Sustainable management of biological solids in small treatment plants: overview of strategies and reuse options for a solar drying facility in Poland
}

\author{
Joanna Boguniewicz-Zablocka ${ }^{1} \cdot$ Iwona Klosok-Bazan ${ }^{1} \cdot$ Andrea G. Capodaglio ${ }^{2}$ (I) \\ Received: 17 April 2020 / Accepted: 20 July 2020 / Published online: 24 July 2020 \\ (C) The Author(s) 2020
}

\begin{abstract}
The issue of sustainable management of biosolids (excess sludge) from wastewater treatment is an important issue in the entire developed world. Residual sludge disposal costs and environmental impact may be significant, and reducing such costs, as well as the energy consumption for dewatering and drying, is a key issue for safe and sustainable sludge disposal, considering the recent ban of some disposal options, such as landfilling, in many European countries. An alternative to thermal technologies is solar drying (not to be confused with bio-drying, very close to the concept of composting). Solar greenhouse drying technology is characterized by reduced land requirements compared with traditional outdoor drying beds, as well as by low-energy requirements compared with other thermal drying methods. Process operation is cost-efficient, with close to no maintenance, and observed specific evaporation rates up to threefold higher than conventional drying beds. Many applications of this technology exist in Poland, Germany and Austria: more than 10,000 t of wet sludge per year is treated in this way in Germany alone and almost as many (9000 t/year) in Poland. This paper examines current biosolids treatment technologies applicable to small wastewater treatment plants (2000-9999 population equivalents served) and opportunities for possible solids reuse in Poland in view of sustainable circular economy schemes. In particular, a purely solar-driven greenhouse facility for sewage sludge drying was investigated under different conditions (season, temperature, environmental humidity) and possible improvements for its efficiency evaluated. Sludge processed by solar drying could have different final disposal pathways, according to season, in accordance with the prescriptions of the new National Waste Management Plan of Poland.
\end{abstract}

Keywords Sewage sludge $\cdot$ Sludge disposal $\cdot$ Sludge drying $\cdot$ Biosolids reuse $\cdot$ Sustainability

\section{Introduction}

Large quantities of residual biosolids (excess sewage sludge) are produced in wastewater treatment plants (WWTPs) worldwide. Safe disposal of waste sludge is an important issue as at the European Union level, since its production is estimated to exceed 14 million tons (dry weight, d.w.) in year 2020. Disposal costs may be significant, up and above $50 \%$ of the

Responsible Editor: Ta Yeong Wu

Andrea G. Capodaglio andrea.capodaglio@unipv.it

1 Department of Thermal Engineering and Industrial Facilities, Faculty of Mechanical Engineering, Opole University of Technology, Opole, Poland

2 Department of Civil Engineering and Architecture, University of Pavia, 27100 Pavia, Italy operational costs of a WWTP, and may contribute around $40 \%$ of greenhouse gas (GHGs) emissions associated with it (Callegari and Capodaglio 2018). Most disposal options rely on specific processes to reduce sludge volume and weight (raw sludge water content is in excess of 97\%) and stabilize residual organics and pathogens, which make handling unsanitary and overly expensive. Water content reduction is highly energy demanding, with an efficiency benchmark set by the thermodynamic requirement for evaporation, approximately $0.63 \mathrm{kWh} / \mathrm{kg}$. In practice, depending on original sludge humidity and actual applied technology, this energy demand may be around $2500 \mathrm{kWh} /$ ton d.w. (Capodaglio and Olsson 2020). Reducing energy consumption of sludge dewatering is therefore a key issue for sludge disposal, in view of limitations foreseen for some current options, such as landfilling (Bień and Bień 2015). Other options (e.g. land application), widely common in the past, are limited by metals and other hazardous pollutants content, due to their potential direct or indirect 
(linked to environmental accumulation) health effects: regulations concerning sludge disposal are getting increasingly restrictive in many countries. Agricultural sludge disposal in Europe decreased from $98.6 \%$ in 1985 to $78 \%$ in 2015 (Eurostat 2019). Following concerns about harmful compounds build-up in soils following agricultural application, 16 EU members have introduced stricter requirements for metals content, while some, including Finland, Slovenia, Sweden, the Netherlands, Greece and Belgium, have completely prohibited disposal of untreated sludge on soil. Initially regarded as appropriate strategy for improving soil productivity by increasing organic matter and nutrient content, land disposal of untreated sludge is becoming largely unacceptable by public opinion, in consideration of many demonstrated or perceived detrimental environmental effects.

It was estimated that sludge produced in Poland in 2018 exceeded 0.7 Mt, mostly disposed of in agriculture (National Waste Management Plan 2010). This is viewed unfavourably by the Polish Government in terms of commitments to EU Directives and of adverse environmental impact, with alternative sustainable solutions being investigated (Werle and Sobek 2019). Thermal processing of more than $30 \%$ of all biologic waste is recommended by the latest Polish National Waste Management Plan (NWMP); however, due to its high costs, this solution is only applicable in large urban agglomerations (Przydatek and Wota 2020).

This paper examines current biosolids thermal treatment technologies applicable to small wastewater treatment plants (2000-9999 population equivalents, PE) and opportunities for solids reuse in Poland under sustainable circular economy schemes. In particular, solar drying of sewage sludge from a small facility was investigated under different operating conditions in order to assess this process' limitations. Due to the relative technological simplicity of greenhouse drying, and of its adoption mostly in small facilities, this is seldom addressed by detailed investigations; however, its contribution to countrywide sustainable biosolids management may be significant, especially in predominantly rural areas. Improved management of biosolids at small facilities could facilitate their inclusion in efficient, regional disposal schemes. Process improvement and sludge final disposal options in accordance with the prescriptions of new National Plan are also discussed.

\section{Properties of biosolids}

Properties and quantities of WWTPs' residual biosolids are closely linked to the characteristics of the contributing catchment and of the treatment facility. The latter, in particular, has a considerable influence on their production: aerobic processes, with faster kinetics, generally produce greater amounts of excess biomass, with some notable exceptions (i.e. granular aerobic sludge, membrane processes); slower anaerobic processes kinetics (i.e. UASBs, EGSPs) generate less. It was estimated that the energy required for sludge disposal ranges between 50 and $100 \mathrm{kWh} / \mathrm{m}^{3}$ wastewater treated in aerobic facilities, compared with $5 \mathrm{kWh} / \mathrm{m}^{3}$ in anaerobic ones (Bruce and Fisher 1984), and this is one of the many reasons prompting the latter's adoption under new urban sewerage sustainability paradigms (Zeeman et al. 2008; Capodaglio et al. 2016b; Capodaglio 2020). Other microbially based unconventional processes, such as bioelectrochemical processes, may generate even less waste sludge (Callegari et al. 2018a).

Biosolids on average contain $20-41 \%$ carbon, $1.5-5 \%$ nitrogen and $0.2-11 \%$ phosphorus (d.w.), making them a potentially interesting substrate for nutrients and/or energy recovery (Daneshgar et al. 2019). However, they may also contain variable amounts of metals and organic contaminants, including chlorinated and perfluorinated compounds, biphenyls, hydrocarbons, antibiotics and pharmaceuticals, quaternary ammonium compounds, steroids and others. In addition, they may contain undesirable microorganisms, pathogenic (Salmonellae) and not (e.g. Escherichia coli, faecal coliforms, clostridia, coliphages). All these are key issues limiting biosolids reuse and recycling options.

Excess sludge is also a chemical energy concentrate. Wastewater organics embed an energy content estimated at $3.86-8.3 \mathrm{kWh} / \mathrm{kg} \mathrm{COD}_{\text {oxidized }}$, the range representing different measurement procedures (Capodaglio and Olsson 2020). Sludge volatile-to-total solids ratio is about 5 times higher than raw wastewater's (around 0.10), with proportionally higher specific embedded energy. For this reason, sewage sludge is looked at with increasing interest as feedstock for the production of renewable fuels (Capodaglio and Callegari 2018).

\section{Biosolids sustainable disposal}

An important step towards environmental sustainability and practical implementation of water cycle circular economy can be achieved by strategies aiming at the maximization of the value of excess biosolids, at the same time minimizing cost and environmental impacts throughout their life cycle. Simple, safe and cost-effective management alternatives should stress locally compatible approaches for reclamation of resources. A sludge disposal technology, to be considered sustainable, should generate a stabilized and disinfected final product with added value, easy to handle, while being easy to maintain and operate.

As mentioned, the most important beneficial uses of municipal biosolids involve the exploitation of embedded energy and resources (mostly nutrients). Land application of untreated biosolids, a common practice in the past, is currently frowned upon, if not outright banned, in most situations due to potentially adverse impacts. In order to limit those, thermal processing of sludge remains perhaps one of the most 
straightforward approaches for disposal of waste sludge without excessive secondary pollution and risks, allowing some forms of energy and resources recovery (Capodaglio et al. 2016a). Until a few years ago, incineration was one of the few technologies believed to adequately deal with sludge not suitable to agricultural use (Englande and Reimers 2001). Recently, progresses in processes such as pyrolysis, hydrothermal carbonisation (HTC) and gasification allow transformation of biosolids into biochar or hydrochar form (Bolognesi et al. 2019) or syngas (Werle and Sobek 2019).

Some of these approaches, readily implementable in medium-/large-scale wastewater treatment facilities, may however be too challenging for small plants, such as those of many small towns in the Polish countryside, a large fraction of the over 3200 operating in the country, most of them biological (with about a quarter of them designed for nutrients removal) (Przydatek and Wota 2020). Only a small amount (estimated at $<30 \%$, short of NWMP targets) of sludge produced in Poland is thermally utilized today, with large amounts (almost nine-folds the annual production) left accumulating on landfill areas near WWTPs (Werle and Sobek 2019). Polish law changes following EU Directives are prompting new approach paradigms and improved technologies for sludge disposal (NWMP-2022 2016).

\section{Biosolids dewatering and drying}

Sludge dewatering and drying are fundamental steps in any sustainable sludge management strategy. The former must not be confused with the latter: one reduces free water content so that solids in sludge reach about $20 \%$, allowing its handling like a semisolid material. This can be achieved mechanically using filter/belt presses, centrifuges, geomembranes, open drying beds and other processes. Drying, on the other hand, is normally achieved through thermal processes evaporating bound water to reach a final solids content of about $90 \%$. Recent technologies combine dewatering and drying in a single step. Drying significantly reduces sludge environmental impact, producing a stabilized, dry granular product more easily transported and better suited for agricultural use (where permitted) since nutrients are mostly retained within and other problematic components are eliminated/immobilized. The drying process also adds value to the residuals, enhancing the efficiency of many reuse and recovery technologies.

\section{Thermal treatment and resource recovery}

Among thermal treatment options, incineration is considered a safe technology for energy recovery from waste and sludge, although sometimes viewed by public opinion with criticism, due to atmospheric emissions and hazardous residues issues. Pyrolysis, a thermochemical decomposition in the absence of oxidizing agents, is also increasingly used. This process rearranges chemical bonds of organic molecules, producing residual solid, gaseous and liquid fractions with fuel and/or material value. Pyrolysis can be achieved with energy input from different sources (fossil, electric, radiation) in different operating conditions (Callegari et al. 2020). Gasification, a thermochemical decomposition in an oxygen-depleted environment, is used to maximize gas production (Werle and Sobek 2019).

Thermal processing is energy-intensive: the large quantities of water in sludge (primary sludge contains around 93-97\%, secondary 98-99\%) severely limit its recovery efficiency. Unless initial sludge humidity is below $30 \%$, more energy is required for drying than is generated by combustion (Callegari et al. 2018b). The breakeven point for energy recovery from sludge combustion was determined to be $27 \%$ water content; however, the use of dry sludge ( $>90 \%$ solids) is normally considered more appropriate to successfully recover its energy content (Andriessen et al. 2019). Mechanically dewatered sludge cannot be incinerated autothermally (at process temperature $>850^{\circ} \mathrm{C}$ ) without auxiliary fuel, with high operational cost. Energy-positive pyrolysis occurs at feedstock humidity below 10\% (Raček et al. 2017). Pyrolysis and gasification, unlike incineration, generate forms of storable energy (e.g. bio-oil, biochar, syngas) and other residuals suitable to feed circular economy circuits.

Emergy assessment could help to identify the most sustainable processes to achieve economic and social benefits with minimal environmental impact. Emergy analysis is a method of accounting materials' embodied energy by expressing all the considered streams and processes in solar energy equivalents. It can then be used to compare different biosolid management alternatives. An emergy-based sustainability assessment of biosolids disposal options confirmed that gasification is energetically and environmentally suitable for biosolids disposal, and pre-processing of biosolids prior to their use in agriculture was shown to improve sustainability performance of this option (Cano Londoño et al. 2017).

The use of thermal drying as pretreatment prior to final residuals disposal is encouraged and increasing. This allows volume, weight and transportation costs reduction and inhibition of biochemical reactions that may occur in the presence of excess residual humidity, allowing safer storage and contamination hazards reduction. In practical applications, depending on technology, drying requirements range from 0.82 to $1.1 \mathrm{kWh} / \mathrm{kg}$ sludge, with innovative combined processes claiming values as low as $0.24 \mathrm{kWh} / \mathrm{kg}$ (Shincci Energy 2019). Despite the increasing diffusion of drying processes, their application is still economically and technically challenging. Energy for evaporation can be supplied by electric, fossil or microwave sources through conduction, convection, radiation and other processes, requiring high temperatures and constant airflow to extract saturated vapour from substrate. Main 
thermal drying technologies are tunnel or rotary drying (Chen et al. 2015; Treviño Arjona and Rodríguez Cisneros 2005). Energy requirements of current drying technologies are summarized in Table 1.

\section{Recoverable energy and products from dried biomasses}

Pyrolysis generates liquid (a.k.a. bio-oil, py-oil), solid (biochar) and gaseous (syngas, py-gas) recoverable phases; gasification produces syngas and solid residues. Py-oil is a liquid product similar in composition to biodiesel from energy crops and diesel fuel, although with higher content of impurities. Its low calorific value (LCV) is lower than energy crops biofuel, $33-35 \mathrm{MJ} / \mathrm{kg}$, against those from corn and safflower $(42-43 \mathrm{MJ} / \mathrm{kg}$ ) and of fossil fuel $(\sim 30 \%$ lower than diesel), depending on process conditions (Capodaglio and Dondi 2016).

Biochar is a "porous carbonaceous solid produced by thermochemical conversion of organic materials in oxygen depleted atmosphere that has physicochemical properties suitable for safe and long-term storage of carbon in the environment" (Shackley et al. 2012), with energy value of $15-18 \mathrm{MJ} / \mathrm{kg}$, depending on feedstock and process. It could be burned for energy; however, it has significant other uses, e.g. improvement of soil productivity (carbon and nutrient content), remediation of contaminated soils (high adsorption potential) and mitigating effects of climate change (long-term carbon fixation). Researchers have shown that biochar can minimize metals release, lowering environmental impacts as soil improver, compared with untreated sludge (Racek et al. 2019).

Syngas is primarily composed of hydrogen and carbon monoxide, with smaller quantities of methane, carbon dioxide, water and low molecular-weight volatiles. Its heating value may vary according to process conditions (normally about $6 \mathrm{MJ} / \mathrm{kg}$ in pyrolysis, higher in gasification).

It should be remembered that recovery processes of all these products are energetically sustainable when feedstock sludge humidity is below about $10 \%$; however, the energy

Table 1 Energy requirements of current biosolids drying technologies

\begin{tabular}{ll}
\hline Technology & $\begin{array}{l}\text { Energy } \\
\left(\mathrm{kWh} / \mathrm{L}_{\text {water }}\right)\end{array}$ \\
\hline Low temperature spiral press/evaporator & $\mathrm{a}$ \\
Band dryer & 0.24 \\
Paddle dryer & 0.82 \\
Flash dryers & 0.95 \\
Rotary dryers & 1.05 \\
Drum & 1.05 \\
Fluid bed & 1.07 \\
\hline
\end{tabular}

${ }^{\text {a }}$ According to (Shincci energy 2019) required to initially dry sludge to that level must also be included in a process' sustainability analysis.

\section{Polish biosolids disposal perspective}

The number of biological WWTPs in Poland increased in recent years, serving a greater share of previously unconnected population, with dismission of older facilities based only on mechanical treatment. Sewage sludge production has thus considerably increased, with a general lack of facilities for thermal disposal. While in large urban areas sludge is converted into energy in heating or power plants, smaller cities are left with fewer choices. There are currently only about 30 thermal sludge drying installations in Poland, based mostly on belt dryers using natural gas as energy source, servicing large (> 99,000 PE) municipal WWTPs. Due to the scarcity of disposal facilities available, thermal disposal is more expensive than average elsewhere the EU, as shown in Table 2, comparing EU and Polish disposal costs for various process options based on standard dewatered sludge ( $\sim 80 \%$ humidity) as base feedstock (Kacprzak et al. 2017). This partly explains local sludge management choices, where agricultural, soil amendment and composting comprise about $50 \%$ of final destinations, while thermal still remains below $30 \%$ (Statistics Poland 2019). In small-medium size plants, there is hence ample margin to increase the efficiency of energy recovery from sludge residuals. Given the largely rural economy of the country, the most interesting recovery options lie especially in sustainable soil-oriented applications, including nutrient (phosphorous) recycling, a finite resource (Daneshgar et al. 2018a).

Gasification is a popular technology in Poland, mostly associated with the countrywide diffusion of agricultural biomasses conversion plants. Incidentally, it should be noted that the residual solid fraction of the biomass gasification process consists of over $20 \% \mathrm{P}_{2} \mathrm{O}_{5}$ (natural phosphate rock contains about $28 \%$ ) and that studies showed $>73 \%$ efficiency of phosphorus recovery from gasification solid residuals leaching (Gorazda et al. 2017). Co-combustion with fossil fuels (coal,

Table 2 Cost comparison of average sludge disposal options in Poland and the EU (based on (Kacprzak et al. 2017))

\begin{tabular}{lll}
\hline Method of disposal & $\begin{array}{l}\text { Polish cost } \\
(\text { Euro/t) }\end{array}$ & $\begin{array}{l}\text { Average EU } \\
\text { cost (Euro/t) }\end{array}$ \\
\hline Agriculture & 75 & $160-210^{\mathrm{a}}$ \\
Forestry & 75 & 240 \\
Composting & 150 & 310 \\
Incineration $^{\mathrm{b}}$ & $375-438^{\mathrm{c}}$ & 315 \\
Landfilling $^{\mathrm{a}}$ & 125 & 255 \\
\hline
\end{tabular}

${ }^{\mathrm{a}}$ Higher figure refers to dried sludge

${ }^{\mathrm{b}}$ Excluding cost recovery from produced energy

${ }^{\mathrm{c}}$ Co-incineration and mono-incineration, respectively 
lignite, wood) and municipal solid waste is also considered an interesting option, as it requires little or no additional investment to add small quantities of sludge the mass of burned fuel. However, two obstacles undermine the wider implementation of such methods in Poland: the first is public acceptance, and the second is purely economic. Public concern and prejudice against combustion plants must be properly addressed by institutional support strategies and incentives (Capodaglio et al. 2016c). According to the NWMP-2022, thermally treated sewage sludge fraction should increase substantially in coming years.

\section{Solar drying of biosolids}

An alternative to energy-intensive thermal technologies for sludge drying is the use of free solar energy. Solar drying is an effective method of applying solar radiation with the aim of eliminating activity of microorganisms and excess humidity content to many agricultural products and organic process residuals, including sludge. Among the various existing solar dryer types, greenhouse dryers have numerous advantages over others, making them a good process alternative for excess sewage sludge processing (Singh et al. 2018). The aim of the process is to accelerate water elimination from the substrate by exploiting an artificial indoor environment in which vapour pressure equilibrium between sludge and ambient air is inhibited by forced ventilation. Solar drying is not to be confused with bio-drying, an alternative method aiming at water removal using heat generated by aerobic organics degradation, conceptually very close to composting (Bennamoun 2012).

These systems are based on an improved greenhouse scheme: concrete flooring with integrated drainage and enclosure by transparent covering (plastic foil, glass or Plexiglas) allow high transmittance of incoming radiation. The impermeable floor surface is profiled with small channels in such a way that free excess water is collected, flowing to a collection sump well, from where it can pumped back into the liquid process units. However, since the drying sludge has already been dewatered prior to layering into the greenhouse, there is normally little free water collected by the drains. Mechanical sludge mixers support moisture transfer from the bulk of the sludge to the surface in contact with the drying air: as shown by Krawczyk (2019), adequate sludge bulk mixing is more efficient than operation at reduced sludge layer thickness. Mechanically, dewatered sludge is spread in layers of 20$50 \mathrm{~cm}$; frequent mixing and continuous aeration ensure odour-free and efficient drying. The structures are fitted with exhaust air fans and ventilation louvers to control air exchange and introduce fresh air, optimizing the drying potential of the indoor environment. Suspended, horizontally mounted fans provide air turbulence on the sludge surface to enhance humidity removal rates. The main liquid transfer phenomena occur at the surface boundary layer, at a rate $W$ be expressed by the following:

$W=A \cdot k_{y}\left(Y_{s}-Y\right)$

where $A$ is the surface area, $k_{\mathrm{y}}$ the mass transfer coefficient and $Y_{\mathrm{s}}$ and $Y$ the moisture content in saturated air and in the main air flow, respectively (Krawczyk 2016). From Eq. (1), it can be seen that water evaporation is driven by the air moisture gradient and by the mass transfer coefficient value, mainly depending on the linear velocity of air. All relevant parameters (temperature of sludge and air, relative humidity of internal and ambient air, radiation, wind speed and sludge moisture content) are continuously measured by automated control systems to maximize process effectiveness.

These systems show low specific energy consumption (as low as $0.28 \mathrm{kWh} / \mathrm{kg}$ evaporated water for nonflocculated sludge, $0.22 \mathrm{kWh} / \mathrm{kg}$ for flocculated sludge), favourably comparing with the $0.82-1.1 \mathrm{kWh} / \mathrm{kg}$ normally required by thermal drying (as shown in Table 1). About half of this requirement is due to the ventilation system operation. In warmer countries, with temperatures in the range $26-47{ }^{\circ} \mathrm{C}$, openairflow greenhouses may be more efficient than climatecontrolled ones, without energy requirements except for sludge turning (Belloulid et al. 2019).

Solar drying has shown additional effects on sludge characteristics and composition, causing increase of humic-like substances, decreasing sludge lipids content by complexification of organic matter, favouring its application for long-term organic amendment in land farming (Collard et al. 2017). Sludge overturning frequency can improve overall process efficiency, similarly to what seen in composting and bio-drying (Zhao et al. 2010). A study on open-air drying in warm climate (Arizona, USA) showed that solar drying could promote nitrogen loss via ammonia volatilisation. Dried sludge showed relatively stable organic nitrogen content, with declining ammonium-nitrogen $\left(\mathrm{NH}_{4}{ }^{+}-\mathrm{N}\right)$ content proportional to moisture loss (O'Shaughnessy et al. 2008).

As part of the solar drying process, odours and pathogen issues may be curtailed. A study in Australia showed reduction of viruses, helminths and bacterial indicators (Salmonella sp. and E. coli). Results for bacterial pathogens (i.e. faecal coliforms) were however inconclusive (Shanahan et al. 2010). A study in Turkey showed that solar drying achieved 1-log reduction of coliform counts within a 45-days, which increased to $4-\log$ reduction in just 5 days by addition of $15 \%$ (by weight) lime (Salihoglu et al. 2007); under prevailing Polish climatic conditions, however, solar drying of sludge may not guarantee a product void of pathogenic microorganisms for process times shorter than 4 weeks (Sypuła et al. 2013).

Solar drying process output is a product in granular form (1-5 mm) or dust; apart from higher specific calorific value $(\approx$ $8 \mathrm{MJ} / \mathrm{kg}$ ) compared with raw sludge, this material has good 
transportability characteristics (bulk density $\approx 700 \mathrm{~kg} / \mathrm{m}^{3}$ ) (Garanto 2016).

Solar drying technology is marked by reduced surface requirements compared with outdoor drying, as well as by lowenergy requirements compared with thermal drying. These dryers are popular in small WWTPs, with many existing applications in Germany, treating more than $10,000 \mathrm{t}$ of wet sludge per year, and Austria, countries with climate similar to Poland, where about 9000 t/year is treated annually in this way. Processing is considered cost-efficient, with little maintenance and observed specific evaporation rates up to threefold higher than conventional drying beds (Bux et al. 2002). Its use, however, is limited to small installations as it cannot handle large quantities of sludge due to slow process and low applicable loading rates.

\section{Solar drying application: case study}

This case study addresses the effectiveness of sewage sludge solar drying and possible options for its sustainable final disposal. The WWTP (3200 PE) generating the sludge is located in Ujazd, Opolskie Voivodeship. The plant was built in the 1990s and produces between 300 and 400 t/year of raw sludge, with $>98 \%$ moisture content. The sludge undergoes preliminary conditioning (thickening and filtration pressing) that removes up to $9-12 \%$ humidity. Until 2013, when the practice was banned by law, press-filtered sludge was stored together with municipal solid waste after stabilization (liming) in open-air heaps. The greenhouse solar drying facility was built in 2014 to reduce sludge volume and improve its management. Although in the south-western part of Poland climatic conditions are not ideally suited for such solutions, the choice of process was primarily due to its low initial economic investment. After a few years of operation, however, performance showed some limits on expected targets. Dried sludge is so far used mainly in agriculture, and only partly in cocombustion facilities, due to their low humidity $(<10 \%)$ gate requirement. The issue of sustainable final disposal still remains partly unsolved, as agriculture can currently adsorb only a limited quantity of the production, and specifications for co-combustion are not always consistently achieved. In order to better understand the process and improve its effectiveness, a prolonged monitoring and characterization study was carried out.

The unit consists of a free-standing structure, with area of $995 \mathrm{~m}^{2}, 8 \mathrm{~m}$ height and $37^{\circ}$ roof slope (Fig. 1a). A concrete platform supports the steel frame with high transmittance, polyethylene foil cover. The drying house is equipped with 8 low-speed horizontally suspended fans ( $1 \mathrm{~kW}$ each) to mix air internally, and a cross-ventilation system, consisting of two tilting louvers $\left(6 \mathrm{~m}^{2}\right)$ coupled with four exhaust air fans ( $1 \mathrm{~kW}$ each) on the opposite wall and controlled by inverters, for air exchange. Average air velocity in the greenhouse is controlled at about $3 \mathrm{~m} / \mathrm{s}$. To achieve better process efficiency, it is necessary to overturn the sludge frequently, which is done by an automated robotic mole (rated power $4.5 \mathrm{~kW}$ ) (Fig. 1b). Mixing also prevents odour formation and release. A schematic view of the drying facility is presented in Fig. 1c. A control programme determines optimal process conditions by monitoring internal and external environmental parameters (air temperature, air humidity, solar radiation and wind speed) with an array of sensors and adjusting the operation of ventilation, aeration hatches and mixing robot. These are the main energy demands by the process, with total installed power of $16.5 \mathrm{~kW}$. Average annual total power requirements can be assessed as about $0.5 \mathrm{kWh} / \mathrm{kg}$ water removed, about $20 \%$ less than the theoretical thermodynamic requirement for thermal evaporation (and 39-55\% less than most thermal technologies), with total annual energy consumption between 130 and $180 \mathrm{MWh}$, depending on sludge quantity.

Sludge is towed to the facility on a trailer, manually unloaded, and spread into a uniform layer. After that, the entire drying process occurs in automated mode without manual intervention, which is only required to remove the dried sludge. In 2019, about $35 \mathrm{t}$ of dry solids were processed, at a specific load of approximately $35 \mathrm{~kg} / \mathrm{m}^{2} /$ year. Standard operation assumes that in summer, when sludge water evaporation is faster, layers should be laid $10-20 \mathrm{~cm}$ deep, while in winter, the bed thickness could increase to $30-40 \mathrm{~cm}$. Faster summer drying allows processing of a $20-\mathrm{cm}$ sludge layer in about 4 weeks, while in the winter, it takes approximately twice to dry a $30-\mathrm{cm}$ layer. The drying process occurs sequentially in batches, with faster summer process time compensating for increased sludge accumulation in winter. Irradiation, mixing and internal climate control allow seasonally variable degrees (75-91\%) of drying and a relatively homogeneous final product for each batch.

Table 3 reports the characteristics of the incoming dewatered sludge during the study. Heavy metals are present at acceptable levels for disposal in agriculture according to Polish regulations.

\section{Operational monitoring}

In order to assess process performance under different operating conditions, monitoring was carried out during two periods: the first started in the cold season (period I, 21 weeks, autumnwinter 2018) and the second in the spring-summer 2019 (period II, 12 weeks). Due to slower evaporation in period I, sludge sampling was performed every 3 weeks, whereas in the spring-summer sampling occurred every 2 weeks. Each time, multiple samples of about $0.2 \mathrm{~kg}$ each were collected at random points through the entire depth of the sludge bed with an Egner stick. These were then mixed and a representative cumulated sample extracted for analysis. To minimize 

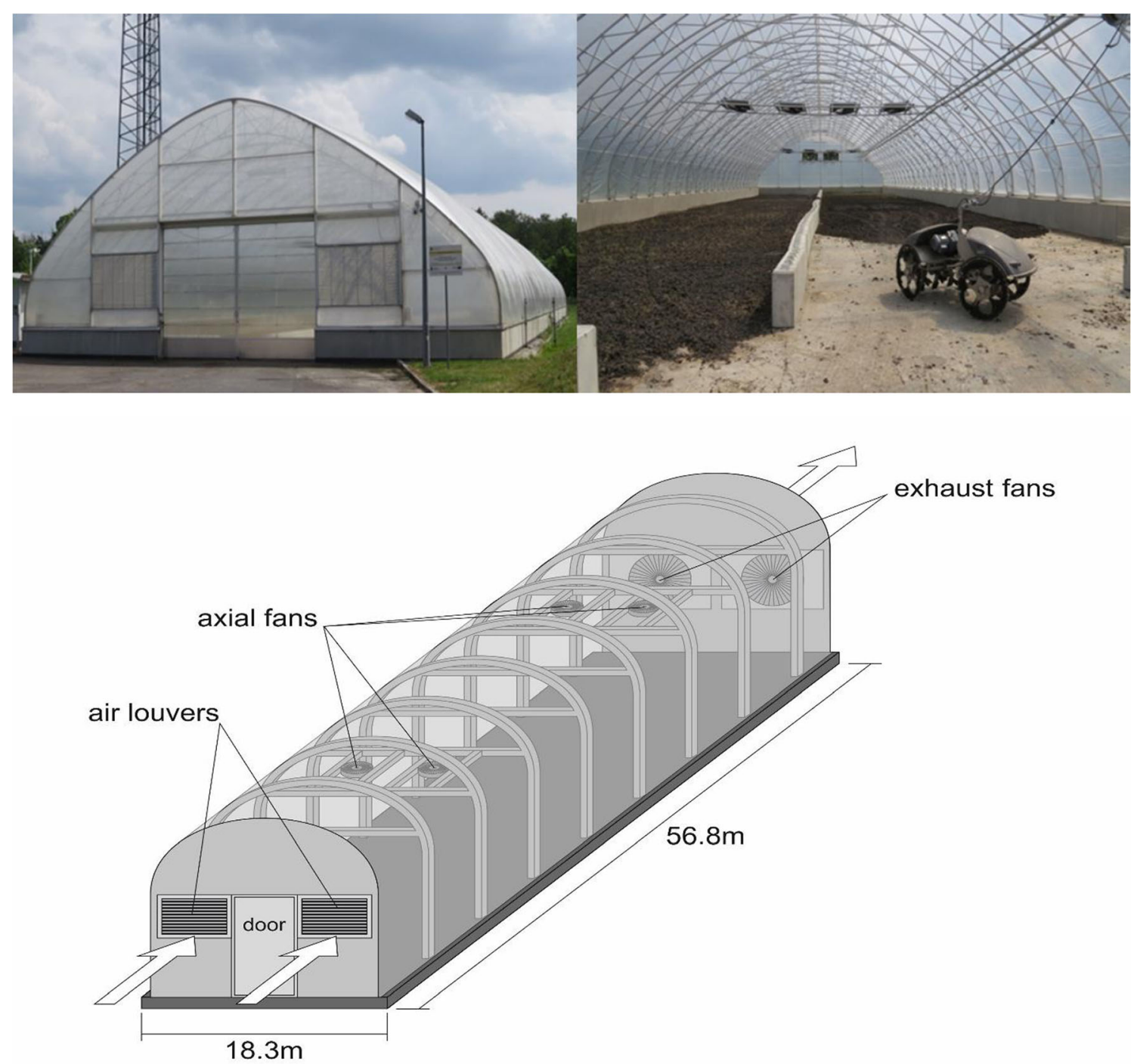

Fig. 1 a Solar drying facility exterior. b Interior, suspended fans and automated turning robot. c Schematic view of the drying facility

measurement errors, the procedure was performed in quadruplicate for each final sample. Collection of incoming sludge samples occurred before and after press dewatering and after drying. Samples were dried at $105^{\circ} \mathrm{C}$ for $12 \mathrm{~h}$ and desiccated; 44 samples (in quadruplicate) were collected in total during the study.

Climatic conditions were monitored outside and inside the greenhouse by the facility's indoor sensors and external weather station, continuously recording internal and external air temperature, indoor and outdoor humidity, solar irradiation and external wind speed. The mean temperature outside the greenhouse ranged from 0 to $15{ }^{\circ} \mathrm{C}$ during study period I and from 10 to $25{ }^{\circ} \mathrm{C}$ in period II. Average values of recorded parameters are shown in Fig. 2.

Indoor temperature remained about $3^{\circ}$ higher than the external one during period I. In general, low insolation was recorded in winter with lowest (daily) irradiation of $25 \mathrm{~W} / \mathrm{m}^{2}$, highest in June $\left(187 \mathrm{~W} / \mathrm{m}^{2}\right)$. Relative average humidity varied considerably, from $60 \%$ in February to $82 \%$ in May, slightly lower than outdoor humidity, fluctuating from $64 \%$ in May to $87 \%$ in December. Large infra-day value fluctuations were observed, e.g. in December in the daily range 70 to $90 \%$, in May from 35 to $75 \%$.

The first processed batch, with sludge layered at $30 \mathrm{~cm}$ height, was monitored from November to June until drying reached $91.94 \%$. In April, a second batch was layered at $20 \mathrm{~cm}$ depth in a separate area of the greenhouse and monitored for 10 weeks. Results are summarized in Table 4 . Humidity of the first sludge batch decreased from 91 to $72 \%$ (Fig. 3a) in 21 weeks during period I. In period II, it further reduced from 72 to $8 \%$. The second batch humidity decreased over $80 \%$ (Fig. 3b) in 10 weeks from 88 to $5.5 \%$. As expected, during winter, when the outdoor average temperature range is $0-6{ }^{\circ} \mathrm{C}$, the process works at lower efficiency. From November to March (period I) the sludge reduced its water content by only $19 \%$. When the average air temperature 
Table 3 Characteristics of dewatered secondary sludge from the experimental campaign

\begin{tabular}{|c|c|c|c|}
\hline Parameter & Unit & Value & $\begin{array}{l}\text { Limit for } \\
\text { agriculture use* }\end{array}$ \\
\hline $\mathrm{pH}$ & - & $6.4 \pm 0.2$ & $>5.6$ \\
\hline Pathogens count & count $/ \mathrm{kg}$ DS & 0 & 0 \\
\hline Salmonella & count/100 g & Not detected & Not detected \\
\hline Dry solids & $\%$ & $93.4 \pm 1.3$ & - \\
\hline Organic C & $\%$ DS & $63.0 \pm 2.7$ & - \\
\hline $\mathrm{N}-\mathrm{NH}_{4}$ & $\% \mathrm{DS}$ & $0.08 \pm 0.02$ & - \\
\hline Total N & $\% \mathrm{DS}$ & $4.11 \pm 0.99$ & - \\
\hline Total P & $\% \mathrm{DS}$ & $1.59 \pm 0.32$ & - \\
\hline $\mathrm{Ca}$ & $\% \mathrm{DS}$ & $3.56 \pm 0.61$ & - \\
\hline $\mathrm{Mg}$ & $\% \mathrm{DS}$ & $0.45 \pm 0.8$ & - \\
\hline $\mathrm{Cr}$ & $\mathrm{mg} / \mathrm{kg} \mathrm{DS}$ & $14.5 \pm 2.5$ & 500 \\
\hline $\mathrm{Zn}$ & $\mathrm{mg} / \mathrm{kg}$ DS & $922 \pm 157$ & 2500 \\
\hline $\mathrm{Cd}$ & $\mathrm{mg} / \mathrm{kg} \mathrm{DS}$ & $1.53 \pm 0.26$ & 20 \\
\hline $\mathrm{Ni}$ & $\mathrm{mg} / \mathrm{kg}$ DS & $14.9 \pm 2.5$ & 300 \\
\hline $\mathrm{Cu}$ & $\mathrm{mg} / \mathrm{kg} \mathrm{DS}$ & $178 \pm 30$ & 1000 \\
\hline $\mathrm{Pb}$ & $\mathrm{mg} / \mathrm{kg}$ DS & $21.8 \pm 3.7$ & 750 \\
\hline $\mathrm{Hg}$ & $\mathrm{mg} / \mathrm{kg}$ DS & $<0.25$ & 16 \\
\hline Calorific value & $\mathrm{MJ} / \mathrm{kg}$ & $14 \pm 0.45$ & - \\
\hline
\end{tabular}

*Legal limits for agricultural use in Poland based on applicable law (Law Journal of Environmental Ministry 2015)

increased above $12{ }^{\circ} \mathrm{C}$, sludge drying rate increased almost instantly. In these conditions, solar drying allows to consistently obtain over $90 \%$ dry solids in 10 weeks or less.

A third batch of sludge was layered $(20 \mathrm{~cm}$ depth) and monitored after period II (period III, June-July). During this period, at average air temperature $>20{ }^{\circ} \mathrm{C}$, sludge drying was fast and humidity reduced by $78 \%$ in just 4 weeks, from 88 to $9.2 \%$.

\section{Results discussion}

To determine the evolution of the process, sludge drying rates were calculated during periods I and II, as the difference between the initial and final sludge mass at each sampling interval (21 or 14 days), assuming an average sludge density of $977 \mathrm{~kg} / \mathrm{m}^{3}$. During winter time, up to week 12 , with average outdoor temperatures between 3 and $9{ }^{\circ} \mathrm{C}$ and air humidity above $70 \%$, average sludge drying rates for batch 1 ranged between about 0.55 and $1.03 \mathrm{~kg} / \mathrm{m}^{2}$ per day. With temperatures between 10 and $14{ }^{\circ} \mathrm{C}$, and humidity between 65 and $70 \%$, drying rates increased up to $1.46 \mathrm{~kg} / \mathrm{m}^{2} /$ day. With outdoor air temperature over $15{ }^{\circ} \mathrm{C}$ and humidity below $65 \%$, drying rates ranged from 1.5 to over $2.5 \mathrm{~kg} / \mathrm{m}^{2} /$ day, an excellent result considering that in this latter phase interstitial and surface water elimination takes place. Initial humidity of batch 1 sludge was $88.16 \%$, final $8.06 \%$, at an average reduction of $2.6 \%$ per week. Figure 4 shows the average daily drying rates calculated for the two test periods. For sludge batch 2 (period II), initial drying rate was $0.77 \mathrm{~kg} / \mathrm{m}^{2} /$ day at outdoor temperature $12-14{ }^{\circ} \mathrm{C}$, increasing up to $1.57 \mathrm{~kg} / \mathrm{m}^{2} /$ day with temperature between 15 and $20^{\circ} \mathrm{C}$ and remaining above $1 \mathrm{~kg} / \mathrm{m}^{2} /$ day in the latter 4 weeks (outdoor temperature $>20^{\circ} \mathrm{C}$ ), starting with a residual humidity below $20 \%$. Batch 2 drying process, starting at $88.28 \%$ and ending at $5.53 \%$ sludge humidity averaged $8.3 \%$ drop per week.

Sludge batch 3 (outdoor air temperature $>20^{\circ} \mathrm{C}$, humidity about $60 \%$ ) showed initial drying rate in the first week of $>$ $50 \%$, decreasing in the second week to about $26 \%$. The average drying rate (starting humidity $88.12 \%$, ending $9.26 \%$ ) was close to a staggering $40 \%$ per week.

While the final moisture content of processed sludge remained below $10 \%$ for all batches, process rate varied significantly during the year, requiring over 5 months to achieve the
Fig. 2 Indoor and outdoor air temperature, solar radiation and humidity during monitoring period

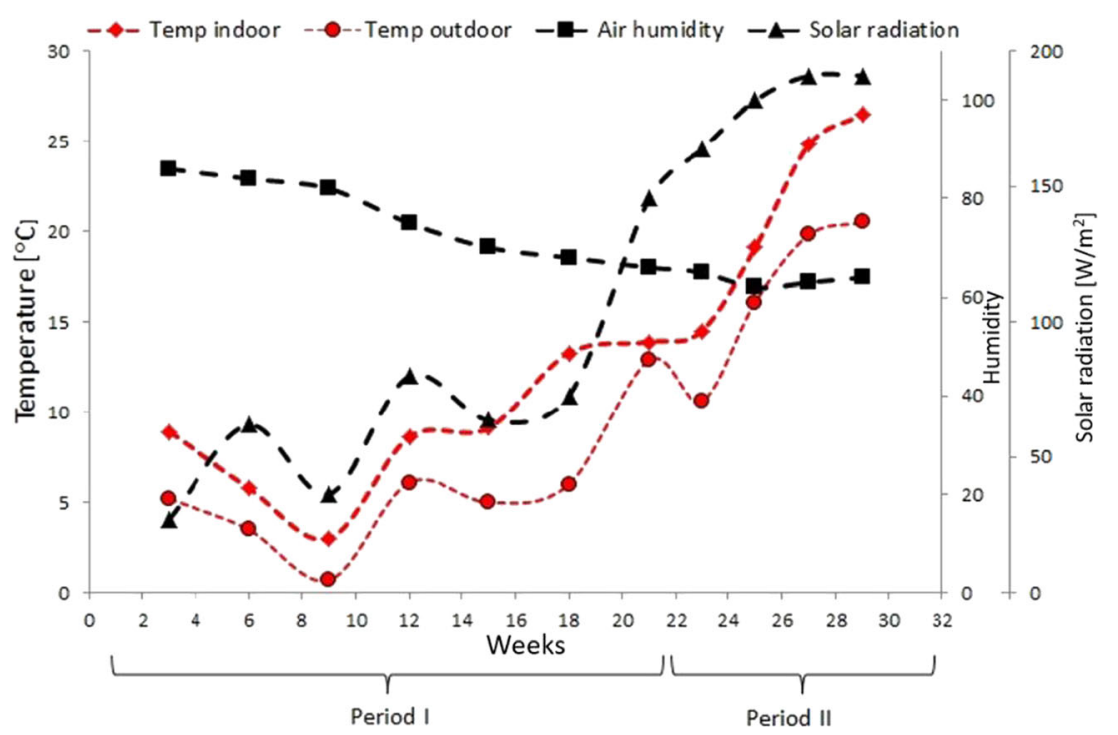


Table 4 Results of sludge solids monitoring

\begin{tabular}{|c|c|c|c|c|c|}
\hline & & Wet sludge mass (g) & Dried sludge mass (g) & Dry solids $(\%)$ & Humidity (\%) \\
\hline \multicolumn{2}{|c|}{ Raw sludge } & 10.16 & 0.19 & 1.89 & 98.11 \\
\hline \multicolumn{2}{|c|}{ Dewatered (press) sludge } & 10.40 & 0.97 & 8.56 & 91.44 \\
\hline Date & Week & \multicolumn{4}{|c|}{ Batch 1-drying house sludge (periods I and II) } \\
\hline 23.11. & 0 & 10.04 & 1.19 & 11.84 & 88.16 \\
\hline 14.12. & 3 & 10.12 & 1.60 & 15.49 & 84.22 \\
\hline 04.01. & 6 & 10.13 & 1.89 & 18.64 & 81.36 \\
\hline 25.01. & 9 & 10.04 & 2.00 & 19.91 & 80.78 \\
\hline 15.02. & 12 & 10.16 & 2.11 & 20.76 & 79.24 \\
\hline 07.03 & 15 & 10.42 & 2.62 & 25.14 & 74.86 \\
\hline 28.03. & 18 & 10.19 & 2.84 & 27.82 & 72.18 \\
\hline 18.04. & 21 & 10.95 & 4.63 & 42.29 & 57.71 \\
\hline 02.05 & 23 & 10.39 & 5.59 & 53.83 & 46.17 \\
\hline 16.05. & 25 & 10.31 & 6.91 & 66.98 & 33.02 \\
\hline 30.05 & 27 & 13.50 & 10.84 & 80.33 & 19.67 \\
\hline \multirow[t]{2}{*}{13.06.} & 29 & 16.62 & 15.26 & 91.94 & 8.06 \\
\hline & & \multicolumn{4}{|c|}{ Batch 2-drying house sludge (period II) } \\
\hline 04.04. & 0 & 10.96 & 1.29 & 11.72 & 88.28 \\
\hline 18.04. & 2 & 10.35 & 2.33 & 22.50 & 77.50 \\
\hline 02.05 & 4 & 10.19 & 4.43 & 43.45 & 56.55 \\
\hline 16.05. & 6 & 9.97 & 6.53 & 65.47 & 34.53 \\
\hline 30.05 & 8 & 10.37 & 8.27 & 78.76 & 20.24 \\
\hline \multirow[t]{2}{*}{13.06.} & 10 & 10.41 & 12.67 & 94.47 & 5.53 \\
\hline & & \multicolumn{4}{|c|}{ Batch 3-drying house sludge (period III) } \\
\hline 17.06 & 0 & 10.02 & 1.19 & 11.88 & 88.12 \\
\hline 24.06 & 1 & 9.95 & 7.46 & 64.34 & 35.66 \\
\hline 01.07 & 2 & 10.22 & 11.93 & 90.74 & 9.26 \\
\hline
\end{tabular}

desired results in winter. Although in the tested conditions the drying effect fulfilled expected requirements, it should be considered that wintertime rates are quite low and that consistent achievement of desired targets could be stressed by a foreseeable future increase of sludge production due to WWTP and sewered area expansions. It is thus necessary to implement solutions that could accelerate the process, are environmentally friendly, costeffective, easily manageable and sustainable.
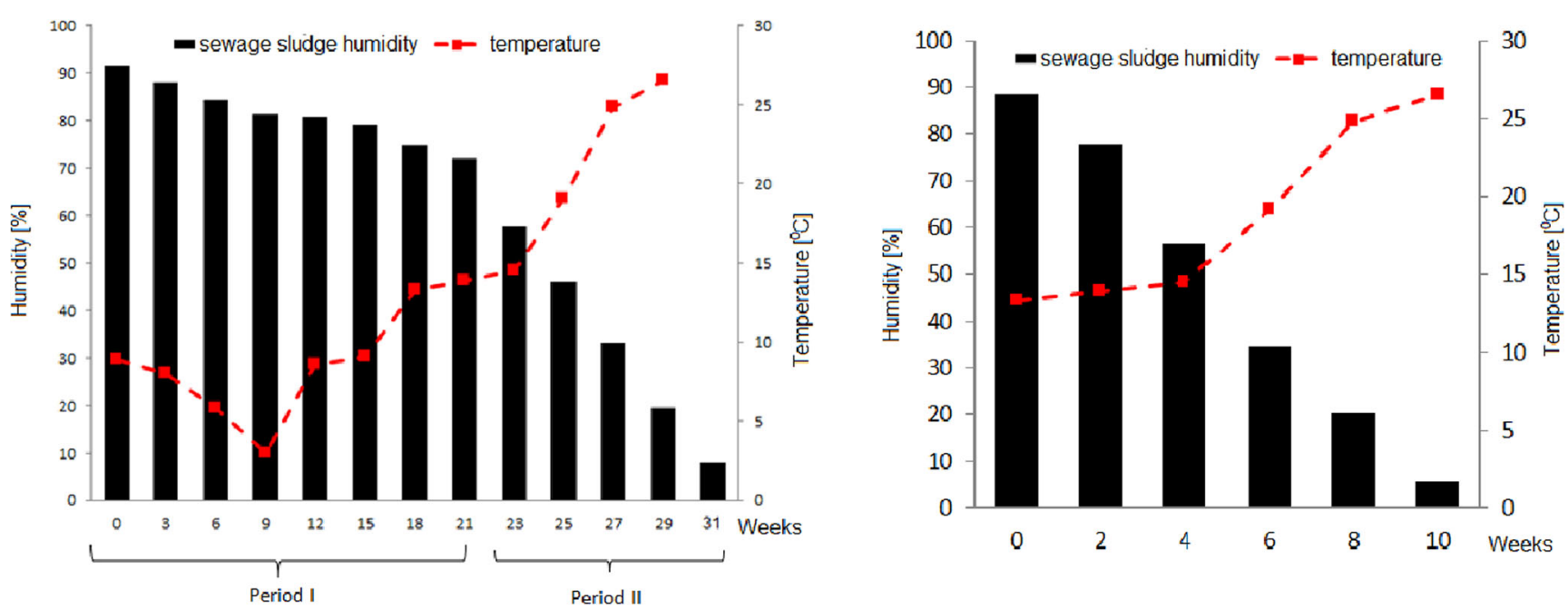

Fig. 3 Sludge humidity during study period. a Batch 1 (periods I and II). b Batch 2 (period II) 
a

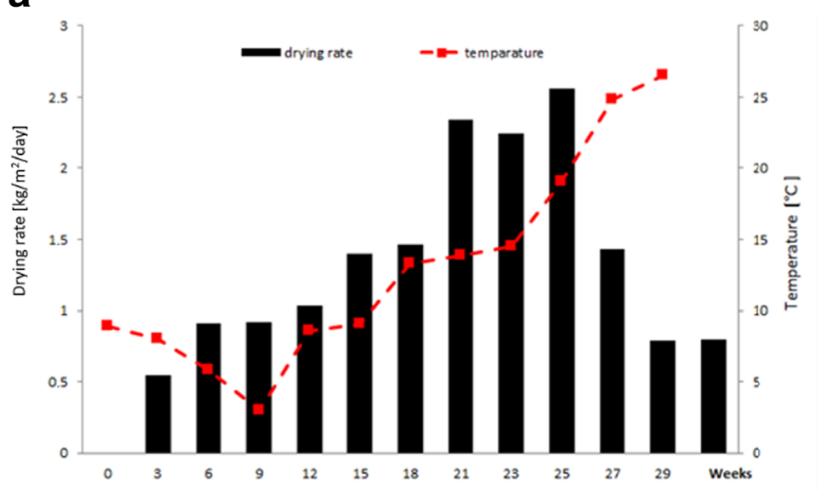

b

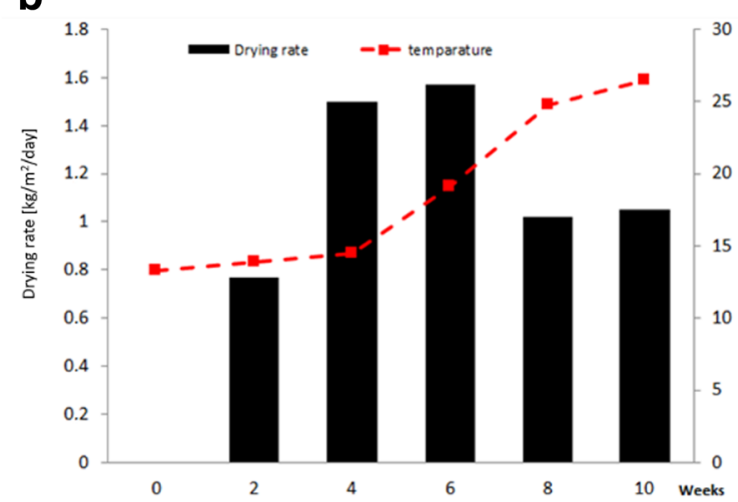

Fig. 4 Calculated drying rates during study period. a Batch 1 (period I). b Batch 2 (period II)

\section{Considerations for process improvement}

Several proposals have been put forward to improve greenhouse dryers performance, including the improvement of insulation; use of modified geometry (i.e. opaque or inclined northern walls) to prevent heat losses and maximize radiation collection, or of internal thermal storage, to improve heat accumulation during limited solar irradiation periods; and improvement of the systems' energetic efficiency by integrating photovoltaic panels or of solar air heaters in greenhouse roofs (Singh et al. 2018).

In view of the study results, possible solutions that could improve rates and efficiency of the process were examined, besides the obvious one of expansion of the drying house, which would not improve process rates but just handling capacity. In order to maintain equal duration of drying periods in winter and summer, or at least reduce winter process time by at least 30\%, volumetric or underfloor heating and/or infrared lamps to increase sludge irradiation were considered, but these would imply both significant initial investment and energy costs, reducing the current attractiveness of solar drying. A specific study on the economics of solar sludge dryers based on 10 years of Polish experiences determined that, due to climatic conditions, it would be technically impossible to implement a hybrid solar/heated system, operating at a constant rate in each month of the year. Two main reasons are as follows: first, no treatment plant in Poland can count on such excesses of generated energy, especially in winter, when any amount of biogas is needed to heat digesters. Second, the significant solar energy deficit could not be compensated by heat pumps recovery, as shown by Cecconet et al. (2020) for use in residential buildings, due to the limited relative capacity of sewer mains or secondary settling tanks from which heat could be extracted and to the maximum possible temperature of the heating medium $\left(50-55^{\circ} \mathrm{C}\right)$. In addition, even if technically possible, this solution would be unsustainably expensive (Trojanowska 2016). Furthermore, additional energy inputs are unlikely to justify any possible gains from process acceleration, as confirmed by experiences in sludge drying greenhouses serving WWTPs in the Polish towns of Klodzko (PE 30,000) and Myszków (PE 40,000), in similar climatic conditions (Bień 2012).

The effectiveness of dynamic adjustment of sludge bed depth according to season was evaluated, under the example of a similarly built and operated facility at the sewage treatment plant of Żagań (Bień and Bień 2015). In that case, bed thickness was set first at $40-45 \mathrm{~cm}$, achieving minimum sludge solids $>60 \%$ in winter. To compensate for lower irradiation, the process was converted to thin layer $(10-20 \mathrm{~cm})$ operation in a shorter winter drying cycle of 18 weeks, achieving sludge $73 \%$ dry solids in December and $67 \%$ in January, showing insignificant improvement over the previous condition.

Mechanical improvement of the sludge cake structure could improve drying capacity by promoting particles agglomeration that would strengthen the skeletal structure of the bed, which could favour water elimination. While the use of physical/chemical conditioners alone may enhance dewatering, but not substantially drying efficiency, a study indicated that mixing locally available clay minerals (bentonite, attapulgite, mixed clays, and zeolite) showed beneficial effects in sewage sludge stabilization and humidity reduction in a Greek greenhouse. An initially highly dewatered sludge (moisture around $84 \%$ ) was dried significantly more effectively in tests with these minerals' addition (Samara et al. 2019). Addition of the minerals showed to increase treated sludge fertilizing value, however, potential environmental impacts (in particular with respect to accumulation of $\mathrm{Ni}, \mathrm{Cr}, \mathrm{Zn}$ and B) as well as possible effects on final disposal options different from agriculture were pointed out. Granulated blast furnace slag, an industrial waste, was also used as sludge skeletal-forming material, forming channels that enhanced the removal of excess water. Slag material did not significantly modify the final properties of the treated sludge that was deemed suitable for applications in construction and agriculture (Ramachandra and Devatha 2020). 
Some major advantages of solar drying, compared with thermal, are that the former's costs and energy consumption are much lower, operation is simple and safe and GHG emissions may be up to seven times lower (Oladejo et al. 2018). In order to maintain environmental sustainability without increasing energy input and emissions, reuse of ambient or waste heat from other sources (i.e. nearby industrial complexes) could be considered, reducing space (area) requirements from three to five times and increasing the capacity of existing facilities (Slim et al. 2008). At the moment, however, no such sources exist in close proximity of this facility.

\section{Sustainable disposal options according to circular economy principles}

The examined facility produces on average $35 \mathrm{t} / \mathrm{year}$ of dried sludge. Although at the moment this can be used as a "class A" fertilizer in agriculture/greenery management, taking into consideration heavy metal content (CEC 1986), it is uncertain how long this will still be feasible according to evolving national rules. Local, sustainable non-agricultural uses were thus examined: the dried product could be suitable as a fuel in waste-to-energy production, coal-fired power plants or cement plants without further processing, as long as the required humidity specifications are fulfilled.

Due to the high internal temperature, a cement kiln creates favourable conditions for co-combustion of dried sludge, while improving production sustainability. Environmental benefits of using sludge in cement production include the following: reduction of land degradation, reduction of fossil materials extraction (coal) and of other fossil fuels consumption, incorporation of all non-combustible parts of waste (slags, ashes) in cement and reduction of GHG emissions. Although no nutrient recovery is achieved, sludge cocombustion in cement kilns is considered among the best and most ecological waste-free disposal solutions in Poland, due to the immobilization of heavy metals into the cement and the limitation of emission of gaseous pollutants (Bożym and Bok 2017). In Poland, which has a thriving cement industry sector, this could therefore be an excellent solution to municipal sewage sludge disposal; however, it may also be a logistically complex endeavour. This applies to securing adequate supply, transportation and storage of sludge at the cement plant, making such a solution justifiable only for facilities located in close proximity. Dried sludge from this facility meets the specified requirements for cement plants concerning contaminants content (metals, sulphur, chlorine); however, its seasonal qualitative variability influences its calorific value; hence, it is currently disposed of in this way for less than $3 \%$ of its production. The cement plant located in Górażdże, 40$\mathrm{km}$ away, is a potential destination, since it could adsorb $1000 \mathrm{t}$ of sludge per year without exceeding the $3 \%$ sludge limit allowable in its input fuel, but requires a dry matter content $>85 \%$ for acceptance, which can safely be reached only in summer or after more than 5-month processing in winter. Dried sludge could also be sent to the Zdzieszowice coking plant, $20 \mathrm{~km}$ away, which is part of ArcelorMittal Poland S.A. that is currently undergoing an expansion after which it could accept around 10,000 t/year of product in the future. In 2018, the plant used just $1125 \mathrm{t}$ of dried sludge from various sources.

Gasification and co-combustion in power boilers may also be considered. Currently, however, co-incineration of sewage sludge is technically considered a process of waste destruction by Polish regulations, not renewable fuel recovery. This involves specific legal, technical and economic issues that hinder the feasibility of these solutions. Therefore, as long specific incentives and favourable regulations are introduced, it is debatable whether these sectors could be interested in this practice. Furthermore, municipal waste incineration plants in Poland are mostly built as facilities dedicated exclusively to municipal waste and do not contemplate acceptance of thermally (including solar dried) processed sewage sludge (Bień and Bień 2015).

Existing biomass digestion plants could accept partially dried sludge (e.g. 12-18-week "winter" sludge), as feedstock for co-digestion. This may be feasible especially for large facilities and could be considered after careful balance between higher transportation costs of the wetter sludge and energy recovery. An incentive in this case is that sludge would be treated as zero-emission material for the purpose of $\mathrm{CO}_{2}$ emissions reduction under this option. Residual sludge after methanation can be reused for co-incineration in biomass fuels mixtures with wood, straw or hard coal or sent to further processing for material recovery.

Wastewater sludge is a good source of nutrients, which is the main reason for its agricultural spreading. As a safer alternative to this practice, phosphorus could be recovered in mineral form from wastewater treatment processes, up to 90\% of its influent amounts (Daneshgar et al. 2018b; Tomei et al. 2020). The Ujazd WWTP, due to its small size, is not suited for P recovery from the liquid treatment train and would require overly complex process modifications in exchange for low expected efficiency. However, other options are available: recovery may be achieved by chemical leaching from P-rich residual ashes after thermal processing of sludge (i.e. combustion, pyrolysis, gasification). Combination of thermal processing and phosphorus extraction from char residues could achieve 70-98\% recovery efficiency (Atienza-Martinez et al. 2014). Another technology applicable to "wet" sludge (around 75-80\% humidity, as achieved in winter after just $12-15$ weeks) with low overall heating value is supercritical water gasification (SCWG) at high temperature $\left(400-600^{\circ} \mathrm{C}\right)$ and short process time (15-60 $\mathrm{min})$. The process could recover $>95 \% \mathrm{P}$ 
by leaching solids with acids (Acelas et al. 2014). Although interesting, this technology would be technically challenging in small facilities or would otherwise imply inefficient long range transfer of wet sludge to a suitable centralized plant.

After considering available options for disposal of the dried Ujazd WWTP sludge, the most sustainable could be conferring it to the Zdzieszowice coking plant (minimum transportation impact, residual value recovery), the second best to transport it to the Górażdże Cement Plant (longer distance, energy recovery mitigation), either one having ample capacity to accommodate this residue. Under current process conditions, however, either would imply at least 5-month winter process time, which would be feasible as long as sludge volumes remain at current levels. As an alternative, winter sludge could undergo a shorter process cycle (12-18 weeks) and sent to a nearby co-digestion facility, under a flexible disposal scheme according to seasonal handling capacity.

\section{Conclusions}

Environmentally sustainable disposal of excess municipal sewage sludge is becoming a major focus of current Polish environmental policy. Unresolved issues concern mainly small and medium wastewater treatment facilities, which lack financial resources to build and operate advanced thermal treatment processes. Solar drying is a diffuse post-processing option in small WWTPs, requiring very low-energy input, reducing cost and environmental impact and making sludge transportation and storage affordable. Drying efficiency, however, depends on degree of irradiation and temperature, which vary throughout the year. In Polish climate conditions, greenhouse drying facilities cannot guarantee constant efficiency and process rates at the highest levels throughout the year, possibly precluding some of the possible options for final disposal in specific periods. Evaluation of all final disposal alternatives and adoption of multi-target, flexible disposal approaches could be an alternative to costly expansion or energetic augmentation of existing facilities.

Acknowledgements Open access funding provided by Università degli Studi di Pavia within the CRUI-CARE Agreement. The authors would like to thank Ms. Sybilla Mojza, M.Sc., for her valuable support and contribution to the discussion on the case study examined.

Open Access This article is licensed under a Creative Commons Attribution 4.0 International License, which permits use, sharing, adaptation, distribution and reproduction in any medium or format, as long as you give appropriate credit to the original author(s) and the source, provide a link to the Creative Commons licence, and indicate if changes were made. The images or other third party material in this article are included in the article's Creative Commons licence, unless indicated otherwise in a credit line to the material. If material is not included in the article's Creative Commons licence and your intended use is not permitted by statutory regulation or exceeds the permitted use, you will need to obtain permission directly from the copyright holder. To view a copy of this licence, visit http://creativecommons.org/licenses/by/4.0/.

\section{References}

Acelas NY, López DP, Brilman DWF, Kersten SRA, Kootstra MJ (2014) Supercritical water gasification of sewage sludge: gas production and phosphorus recovery. Bioresour Technol 174:167-175. https:// doi.org/10.1016/j.biortech.2014.10.003

Andriessen N, Barbara J, Ward BJ, Strande L (2019) To char or not to char? Review of technologies to produce solid fuels for resource recovery from faecal sludge. J Water Sanit Hyg Dev 9(2):210 224. https://doi.org/10.2166/washdev.2019.184

Atienza-Martinez M, Arauzo G, Gea J, Kersten SRA, Kootstra MJ (2014) Phosphorus recovery from sewage sludge char ash. Biomass Bioenergy 65:42-50. https://doi.org/10.1016/j.biombioe.2014.03. 058

Belloulid MO, Hamdi H, Mandi L, Ouazzani N (2019) Solar drying of wastewater sludge: a case study in Marrakesh, Morocco. Environ Technol 40(10):1316-1322. https://doi.org/10.1080/09593330. 2017.1421713

Bennamoun L (2012) Solar drying of wastewater sludge: a review. Renew Sustain Energy Rev 16:1061-1073. https://doi.org/10. 1016/j.rser.2011.10.005

Bień JD (2012) Use of municipal sludge: solar drying of sewage sludge realizations and national experiments (In Polish). In: III National Training Conference "Methods of sewage sludge management", Chorzów, Poland

Bień JD, Bień B (2015) Management of municipal sewage sludge with thermal methods in the face of the landfill ban after 1 January 2016. (in Polish). Ecol Eng 45:36-43

Bolognesi S, Bernardi G, Callegari A, Dondi D, Capodaglio AG (2019) Biochar production from sewage sludge and microalgae mixtures: properties, sustainability and possible role in circular economy. Biomass Convers Biorefinery. https://doi.org/10.1007/s13399-01900572-5

Bożym M, Bok A (2017) Advantages and disadvantages of the solar drying of sewage sludge in Poland. Tech Trans Environ Eng 12: 171-179. https://doi.org/10.4467/2353737XCT.17.217.7760

Bruce AM, Fisher JW (1984) Sewage sludge stabilization and disinfection. Ellis Horwood Limited, Chichester

Bux M, Baumann R, Quadt S, Pinnekamp J, Mühlbauer W (2002) Volume reduction and biological stabilization of sludge in small sewage plants by solar drying. Drying Technol 20(4-5):829-837. https://doi.org/10.1081/DRT-120003765

Callegari A, Capodaglio AG (2018) Properties and beneficial uses of (bio)chars, with special attention to products from sewage sludge pyrolysis. Resources 7:20. https://doi.org/10.3390/ resources 7010020

Callegari A, Cecconet D, Molognoni D, Capodaglio AG (2018a) Sustainable processing of dairy wastewater: long-term pilot application of a bio-electrochemical system. J Clean Prod 189:563-569. https://doi.org/10.1016/j.jclepro.2018.04.129

Callegari A, Hlavinek P, Capodaglio AG (2018b) Production of energy (biodiesel) and recovery of materials (biochar) from pyrolysis of urban waste sludge. Rev Amb Agua 13(2):e2128. https://doi.org/ 10.4136/ambi-agua. 2128

Callegari A, Bolognesi S, Cecconet D, Capodaglio AG (2020) Production technologies, current role, and future prospects of biofuels feedstocks: a state-of-the-art review. Crit Rev Environ Sci Technol 50(4):384-436. https://doi.org/10.1080/10643389.2019.1629801

Cano Londoño NA, Suarez DG, Velasquez HI, Ruiz-Mercado GJ (2017) Emergy analysis for the sustainable utilization of biosolids generated 
in a municipal wastewater treatment plant. J Clean Prod 141:182193. https://doi.org/10.1016/j.jclepro.2016.09.033

Capodaglio AG (2020) Taking the water out of "wastewater": an ineluctable oxymoron for urban water cycle sustainability. Water Environ Res:1-11. https://doi.org/10.1002/wer.1373

Capodaglio AG, Callegari A (2018) Feedstock and process influence on biodiesel produced from waste sewage sludge. J Environ Manag 216:176-182

Capodaglio AG, Dondi D (2016) Selective extraction of liquid fuel from urban wastewater sludge by microwave-controlled pyrolysis. European Biomass Conference and Exhibition Proceedings 2016, Issue 24thEUBCE: 1270-1274

Capodaglio AG, Olsson G (2020) Energy issues in sustainable urban wastewater management: use, demand reduction and recovery in the urban water cycle. Sustainability 12:266

Capodaglio AG, Callegari A, Dondi D (2016a) Microwave-induced pyrolysis for production of sustainable biodiesel from waste sludges. Waste Biomass Valor 7(4):703-709

Capodaglio AG, Ghilardi P, Boguneiwicz-Zablocka J (2016b) New paradigms in urban water management for conservation and sustainability. Water Pract Technol 11(1):176-186

Capodaglio AG, Callegari A, Lopez MV (2016c) European framework for the diffusion of biogas uses: emerging technologies, acceptance, incentive strategies, and institutional-regulatory support. Sustainability 8(4):298

Cecconet D, Raček J, Callegari A, Hlavínek P (2020) Energy recovery from wastewater: a study on heating and cooling of a multipurpose building with sewage-reclaimed heat energy. Sustainability 12:116

Chen G, Yue PL, Mujumdar AS (2015) Dewatering and drying of wastewater treatment sludge. In handbook of industrial drying, 4th ed.; A.S. Mujumdar Ed.; CRC Press: Boca Raton: 867-882

Collard M, Teychen B, Lemee L (2017) Comparison of three different wastewater sludge and their respective drying processes: solar, thermal and reed beds e impact on organic matter characteristics. J Environ Manag 203:760-767

Council of European Communities (1986) Directive on the protection of the environment, and in particular of the soil, when sewage sludge is used in agriculture (86/278/EEC)

Daneshgar S, Callegari A, Capodaglio AG, Vaccari D (2018a) The potential phosphorus crisis: resource conservation and possible escape technologies: a review. Resources 7:37

Daneshgar S, Buttafava A, Callegari A, Capodaglio AG (2018b) Simulations and laboratory tests for assessing phosphorus recovery efficiency from sewage sludge. Resources 7:54

Daneshgar S, Buttafava A, Callegari A, Capodaglio AG (2019) Economic and energetic assessment of different phosphorus recovery options from aerobic sludge. J Clean Prod 223:729-738

Englande AJ, Reimers RS (2001) Biosolids management - sustainable development status and future direction. Wat Sci Tech 44(10):41-46

Eurostat (2019) Sewage sludge production and disposal European Statistical Office, Luxembourg. Available online at https://ec. europa.eu/eurostat/web/products-datasets/-/env ww spd. Accessed 4 Feb 2020

Garanto O (2016) Solar sludge drying technology and dried sludge as renewable energy - closing the loop. J Traffic Transp Eng 4:221229

Gorazda K, Tarko B, Wzorek Z, Kominko H, Nowak AK, Kulczycka J, Henclik A, Smol M (2017) Fertilizer production from ashes after sewage sludge combustion - a strategy towards sustainable development. Environ Res 154:171-180

Kacprzak M, Neczaj E, Fijałkowski K, Grobelak A, Grosser A, Worwag M, Rorat A, Brattebo H, Almås A, RamSingh B (2017) Sewage sludge disposal strategies for sustainable development. Environ Res 156:39-46

Krawczyk P (2016) Control strategy for ventilation system of sewage sludge solar dryer. J Power Tech 96(2):145-148
Krawczyk P (2019) The relative change of drying rate as a function of the cumulative ventilation air drying potential in a thin-layer solar drying facility. IOP Conf Ser Mater Sci Eng 556:012055

Law Journal of Environmental Ministry No 257 (2015) ( Dz.U. poz.257 ROZPORZĄDZENIE MINISTRA ŚRODOWISKA w sprawie komunalnych osadów ściekowych, In Polish) Warsaw, Poland, 25 Feb 2015)

National Waste Management Plan 2014 (2010) The Council of Minister Resolution No. 217 Monitor Polski, No 101 item 1183, Warsaw, Poland

National Waste Management Plan 2022 (2016) Resolution No. 88 of the Council of Ministers of 1 July 2016. Monitor Polski poz. 284, Warsaw, Poland

Oladejo J, Shi K, Luo X, Yang G, Wu T (2018) A review of sludge-toenergy recovery methods. Energies 12:60

O'Shaughnessy SA, Song I, Artiola JF, Choi CY (2008) Nitrogen loss during solar drying of biosolids. Environ Technol 29(1):55-65

Przydatek G, Wota AK (2020) Analysis of the comprehensive management of sewage sludge in Poland. J Mater Cycles Waste Manag 22: 80-88. https://doi.org/10.1007/s10163-019-00937-y

Raček J, Capodaglio AG, Ševčík J, Chorazy T, Hlavínek P (2017) Microwave pyrolysis treatment of sewage sludge: performed at laboratory and full-scale conditions. International Multidisciplinary Scientific GeoConference Surveying Geology and Mining Ecology Management, SGEM 17(43):107-114

Racek J, Sevcik J, Komendova R, Kucerik J, Hlavinek P (2019) Heavy metal fixation in biochar after microwave pyrolysis of sewage sludge. Desal Water Treat 159:79-92

Ramachandra RH, Devatha CP (2020) Experimental investigation on sludge dewatering using granulated blast furnace slag as skeleton material. Environ Sci Pollut Res 27:11870-11881

Salihoglu NK, Pinarli V, Salihoglu G (2007) Solar drying in sludge management in Turkey. Ren Energy 32:1661-1675

Samara E, Matsi T, Zdragas A, Barbayiannis N (2019) Use of clay minerals for sewage sludge stabilization and a preliminary assessment of the treated sludge's fertilization capacity. Environ Sci Pollut Res 26: 35387-35398

Shackley S, Carter S, Knowles T, Middelink E, Haefele S, Sohi S, Cross A, Haszeldine S (2012) Sustainable gasification-biochar systems? A case-study of rice-husk gasification in Cambodia, part 1: context, chemical properties, environmental and health and safety issues. Energy Policy 42:49-58

Shanahan EF, Roiko A, Tindale NW, Thomas MP, Walpole R, Kurtböke DI (2010) Evaluation of pathogen removal in a solar sludge drying facility using microbial indicators. Int J Environ Res Publ Health 7: 565-582

Shincci Energy (2019) Sludge dryer - dewatering \& drying. Available on: $\mathrm{http}: / /$ www.shincci.com/Eproduct/product_100000005042441.html (Accessed 13 Dec 2019)

Singh P, Shrivastava V, Kumar A (2018) Recent developments in greenhouse solar drying: a review. Renew Sustain Energy Rev 82:3250 3262

Slim R, Zoughaib A, Clodic D (2008) Modeling of a solar and heat pump sludge drying system. Int J Refrig 31:1156-1168

Statistics Poland (2009-2016) http://bdl.gov.pl. Accessed 28 september 2019

Sypuła M, Paluszak Z, Szala B (2013) Effect of sewage sludge solar drying technology on inactivation of select indicator microorganisms. Pol J Environ Stud 22:533-540

Tomei MC, Stazi V, Daneshgar S, Capodaglio AG (2020) Holistic approach to phosphorus recovery from urban wastewater: enhanced biological removal combined with precipitation. Sustainability 12 : 575

Treviño Arjona B, Rodríguez Cisneros J (2005) Analysis of drying technologies for wastewater treatment plant sludge as an alternative source of energy. Third LACCEI International Latin American and 
Caribbean Conference for Engineering and Technology (LACCET'2005) "Advances in Engineering and Technology: A Global Perspective", Cartagena de Indias, Colombia

Trojanowska K (2016) Ekonomika słonecznych suszarni osadów ściekowych - przegląd pierwszej dekady polskich doświadczeń (Economics of solar sewage sludge dryers - a review of the first decade of Polish experience, in Polish). Forum Eksploatatora 3(84):56-63

Werle S, Sobek S (2019) Gasification of sewage sludge within a circular economy perspective: a Polish case study. Environ Sci Pollut Res 26:35422-35432
Zeeman G, Kujawa K, de Mes T, Hernandez L, de Graaff M, AbuGhunmi L, Mels A, Meulman B, Temmink H, Buisman C (2008) Anaerobic treatment as a core technology for energy, nutrients and water recovery from source-separated domestic waste(water). Water Sci Technol 57:1207-1212

Zhao L, Gu WM, He PJ, Shao LM (2010) Effect of air-flow rate and turning frequency on bio-drying of dewatered sludge. Water Res 44 : $6144-6152$

Publisher's note Springer Nature remains neutral with regard to jurisdictional claims in published maps and institutional affiliations. 